\title{
Characterization of children submitted to cardiac surgery that developed surgical site infection
}

\section{Caracterização de crianças submetidas à cirurgia cardíaca que desenvolveram infecção de sítio cirúrgico}

\section{Caracterización de los niños sometidos a cirugía cardíaca que desarrollaron una infección del sitio quirúrgico}

\author{
Aurilene Lima da Silva ${ }^{1,2}$, Ticiana Bezerra Castro Pontes², Maria Sinara Farias ${ }^{3, *}$, Maria José Matias \\ Muniz Filha ${ }^{3}$, Solange Gurgel Alexandre ${ }^{4}$, Silvânia Ribeiro ${ }^{7}$
}

\section{ORCID IDS}

Silva AL (D) https://orcid.org/0000-0001-9755-5464

Pontes TBC (D) https://orcid.org/0000-0003-1391-3856

Farias MS (D) http://orcid.org/0000-0002-2695-502X

Muniz Filha JM (iD https://orcid.org/0000-0002-8716-6315

Alexandre SG (iD) https://orcid.org/0000-0001-6742-1043

Ribeiro S (D) https://orcid.org/0000-0001-6391-2136

\section{HOW TO CITE}

Silva AL; Pontes TBC; Farias MS; Muniz Filha JM; Alexandre SG. Caracterização de crianças submetidas à cirurgia cardíaca que desenvolveram infecção de sítio cirúrgico. ESTIMA, Braz. J. Enterostomal Ther., 18: e1820, 2020. https://doi.org/10.30886/ estima.v18.888_IN

\begin{abstract}
Objective: Characterize the clinical and surgical profile of children undergoing cardiac surgery who developed surgical site infection in a public hospital in the city of Fortaleza, Ceará. Methods: Descriptive research with a quantitative approach, developed in a pediatric cardiology unit, with data collected from April to June 2018. The study sample consisted of 26 children with surgical wound infection in the year 2017. Results: There were none gender prevalence; the weight range varied from 3 to $6 \mathrm{~kg}(42.3 \%)$ and neonates had a prevalence of $38 \%$. Corrective surgeries represented $88 \%$ of the total; the surgical time varied from 2 to 6 hours (38\%); $70 \%$ of the children were submitted to cardiopulmonary bypass with the predominant time of 90 to 120 minutes (27\%); the diagnosis of infection was made between 4 and 6 days after the procedure. There was prophylactic antibiotic coverage in $88 \%$ and skin preparation in 92\% of children. Conclusion: Characterizing the clinical-surgical profile of children undergoing cardiac surgery becomes essential for decision-making in the care processes of nurses, emphasizing the findings as a basis for the development of strategies for the prevention of surgical site infection in this clientele.
\end{abstract}

DESCRIPTORS: Surgical site infection; Pediatrics; Cardiac surgery; Enterostomal therapy.

\footnotetext{
1. Hospital Dr. Carlos Alberto Sturdart Gomes - Messejana (CE), Brazil.

2. Universidade Estadual do Ceará - Centro de Ciências da Saúde - Fortaleza (CE), Brazil.

3. Hospital Universitário Walter Cantídio - Fortaleza (CE), Brazil.

4. Hospital Universitário Walter Cantídio - Setor de Clínica médica - Fortaleza (CE), Brazil.

*Correspondence author: sinarafariasbc@gmail.com

Received: May 13, 2020 | Accepted: Aug. 10, 2020
} 


\section{RESUMO}

Objetivo: caracterizar o perfil clínico-cirúrgico de crianças submetidas à cirurgia cardíaca que desenvolveram infecção de sítio cirúrgico em hospital público na cidade de Fortaleza, Ceará. Métodos: pesquisa descritiva com abordagem quantitativa, desenvolvida em unidade de cardiologia pediátrica, com dados coletados nos meses de abril a junho de 2018 . A amostra do estudo foi composta por 26 crianças com infecção de ferida operatória no ano de 2017. Resultados: não houve prevalência de gênero; o intervalo do peso variou de 3 a 6 $\mathrm{kg}(42,3 \%)$ e os neonatos tiveram prevalência de $38 \%$. As cirurgias corretoras representaram $88 \%$ do total; o tempo cirúrgico variou de 2 até 6 horas (38\%); 70\% das crianças foram submetidas a circulação extracorpórea com o tempo predominante de 90 a 120 minutos (27\%); o diagnóstico de infecção foi feito entre 4 a 6 dias após o procedimento. Houve cobertura antibiótica profilática em $88 \%$ e a preparação da pele em 92\% das crianças. Conclusão: caracterizar o perfil clínico-cirúrgico de crianças submetidas à cirurgia cardíaca torna-se imprescindível para a tomada de decisões nos processos de cuidado do enfermeiro, enfatizando os achados como base para o desenvolvimento de estratégias para a prevenção de infeç̧ão de sítio cirúrgico nessa clientela.

DESCRITORES: Infecção de sítio cirúrgico; Pediatria; Cirurgia cardíaca; Estomaterapia.

\section{RESUMEN}

Objetivo: Caracterizar el perfil clínico y quirúrgico de los niños sometidos a cirugía cardíaca que desarrollaron infección del sitio quirúrgico en un hospital público en la ciudad de Fortaleza-Ceará. Método: investigación descriptiva con enfoque cuantitativo, desarrollada en la Unidad de Cardiología Pediátrica, con datos recopilados de abril a junio de 2018. La muestra del estudio consistió en 26 niños con infección de heridas quirúrgicas en el año 2017. Resultados: no hubo ninguno prevalencia de género; el rango de peso varió de 3 a 6 kilos (42.3\%) y los recién nacidos tuvieron una prevalencia de 38\%. Las cirugías correctivas representaron el 88\% del total; el tiempo quirúrgico varió de 2 a 6 horas (38\%); El 70\% de los niños fueron sometidos a bypass cardiopulmonar con un tiempo predominante de 90 a 120 minutos (27\%); El diagnóstico de infección se realizó entre 4 y 6 días después del procedimiento. Hubo cobertura antibiótica profiláctica en el $88 \%$ y preparación de la piel en el $92 \%$ de los niños. Conclusión: caracterizar el perfil clínico-quirúrgico de los niños sometidos a cirugía cardíaca es esencial para la toma de decisiones en los procesos de atención de las enfermeras, enfatizando los hallazgos como base para el desarrollo de estrategias para la prevención de la infección del sitio quirúrgico en esta clientela.

DESCRIPTORES: Infección del sitio quirúrgico; Pediatría; Cirugía del corazón; Estomaterapia.

\section{INTRODUCTION}

Health care-associated infection (HAI) is a major concern of the health services. Among the topographies of the HAIs, the surgical site infection (SSI) is directly related to the surgical procedures, and is currently one of the most important ones ${ }^{1}$.

Along the way to infection control, in 1997, the Brazilian Ministry of Health (BMH) determined that all hospitals in the country should have guidelines and norms for the prevention and control of hospital infections, organized through Hospital Infection Control Programs (HICP), developed by the Commissions for Hospital Infection Control'2.

In 2004, the World Health Organization (WHO) launched the World Alliance for Patient Safety, whose first challenge was health-related infection ${ }^{2}$. In 2007 and 2008, the Safe Surgery Program was created with the objective of increasing the quality standards of care in the fields of surgical site infection prevention, safe anesthesia, safe surgical teams and indicators of surgical assistance ${ }^{3}$.

In Brazil, in 2013, the National Patient Safety Program was created with the objective of contributing to the qualification of care in all healthcare facilities in national territory, being WHO's dictum that patient safety is the reduction of the risk of unnecessary harm associated with health care ${ }^{4}$.

Many are the prevention efforts and programs developed by the competent agencies; however, the SSI remains today as one of the main risks to the safety of patients. According to national studies, the occurrence of SSI ranks 3 rd among the HAIs, comprising 14 to $16 \%$ of those found in hospitalized patients. It is estimated that SSIs can be avoided in up to $60 \%$ of the cases, through the application of orientation and prevention measures ${ }^{4}$.

Pediatric cardiac surgeries represent a highly complex, large and commonly long-lasting procedure, from which the physiological mechanisms that leave the child subject to postoperative complications $s^{5}$ are altered. Based on 
clinical practice in this context, professional actions aimed at infection control, among them the surgical site infection, object of this study, are necessary.

For the nursing performance in the process of care in pediatric cardiac surgery, the assistance provided in a safe way, with decision making based on clear and feasible work processes that favor a reliable clinical practice, is mandatory.

The treatment of thoracic SSI after cardiac surgery in children represents a great challenge, especially when the infection progresses to a mediastinitis. It is reaffirmed that joint actions of a transdisciplinary team are necessary for a favorable outcome. The provision of safe care and assistance to the surgical patient, highlighting the postoperative period, is essential for the identification of risk factors. In addition, knowing the variables involved in the context of infection in the operative wound (OW) is fundamental for a preventive and curative clinical practice of children affected by this event ${ }^{6}$.

In this perspective, faced with the reality experienced in the stages of the Specialization Course in Enterostomal Therapy at the Universidade Estadual do Ceará (UECE), the concern about the work performed with children with SSI arose, awakening the desire for knowledge that would support the development of preventive actions in order to minimize this adverse occurrence.

In this sense, studies focused on nursing care with this public become relevant, in order to redefine the ways of care and to develop strategies such as protocol elaboration, standard operational plan or bundles that help the work process and enable improvements in the quality of service and safety of patients.

Furthermore, it is expected that the literary production of this study will contribute to other researchers, professionals, especially enterostomal therapists, to subsidize their studies about the postsurgical care of children with cardiopathies.

\section{OBJECTIVE}

To characterize the clinical-surgical profile of children submitted to heart surgery who developed a surgical site infection in a public hospital in the city of Fortaleza, Ceará.

\section{METHODS}

It is a retrospective study of documental analysis, with a quantitative approach. This research is part of a larger project, implemented in a pediatric cardiology unit, with a view to reducing infection rates in children undergoing heart surgery. The data were collected from April to June 2018 in a quaternary hospital specialized in the diagnosis and treatment of heart and lung diseases, with capacity to perform highly complex procedures in these areas.

To guide the data collection and achieve the proposed objectives, an instrument used by the hospital's pediatric department was the evolution tool for root cause analysis (ETRCA). This form includes data regarding clinical and epidemiological variables of the hospitalized child with cardiopathies, and the data regarding gender, weight, age range, type of surgery, days after the procedure until the diagnosis of infection, antibiotic therapy, preoperative bath and skin preparation, surgical time, submission and cardiopulmonary bypass $(\mathrm{CPB})$ time and significant factors that may have contributed to the infection were used in this study.

The study population corresponds to 248 children who underwent heart surgery in 2017. The sample totals 26 ETRCA of children who developed surgical site infection confirmed by the Commission for Hospital Infection Control. The eligibility criteria were children with heart disease, of both sexes, aged from birth to 12 years, submitted to heart surgery in the period from January to December 2017.

The data collected were organized in a spreadsheet of the Windows 10 Excel software and analyzed according to descriptive statistics with absolute frequencies, presented in the form of tables that will be discussed in the light of the pertinent literature.

The study observed the Resolution 466/2012 of the National Council of Health, that addresses researches performed with human beings, approved with opinion n. 2.720.317.

\section{RESULTS}

Data regarding the sample are presented below, namely: gender, weight, age, surgical procedure and preoperative SSI preventive actions. Table 1 shows the gender, weight, and age range of the study participants. 
Table 1. Characterization of children undergoing cardiac surgery. Fortaleza, Ceará, 2018.

\begin{tabular}{|c|c|c|}
\hline Gender & $\mathrm{F}$ & $\%$ \\
\hline Female & 13 & 50,0 \\
\hline Male & 13 & 50,0 \\
\hline Weight & $F$ & $\%$ \\
\hline 0 to $3 \mathrm{~kg}$ & 5 & 19.2 \\
\hline f3 to 6 kg & 11 & 42.3 \\
\hline f 6 to 9 kg & 1 & 4.0 \\
\hline f 9 to $12 \mathrm{~kg}$ & 5 & 19.2 \\
\hline$\dashv 12$ to 15 kg & 2 & 7.7 \\
\hline$>15 \mathrm{~kg}$ & 2 & 7.7 \\
\hline Age range & $\mathrm{F}$ & $\%$ \\
\hline Newborn & 10 & 38,0 \\
\hline$>29$ days up to 1 year & 8 & 31,0 \\
\hline$f 1$ anos to 2 years & 6 & 23,0 \\
\hline$>2$ years & 2 & 8,0 \\
\hline
\end{tabular}

Source: Elaborated by the author.

There was no prevalence of gender. As for weight, the range from 3 to $15 \mathrm{~kg}$ represented $42.3 \%$ of children. Regarding age, the age range of newborns (from 0 to 28 days) predominated, with a prevalence of $38 \%$.

Table 2 presents the characteristics of the surgical procedure to which the children participating in the study were submitted.

Corrective surgeries accounted for $88.5 \%$ of surgical procedures. As shown in Table 2, the surgical time between 2 and 6 hours represented $77 \%$ of the total. Of the 26 surgeries performed, CPB was used in $69.2 \%$ of the cases; of these, $27 \%$ lasted from 90 to 120 minutes. The amount from 4 to 6 days after the procedure until the diagnosis of infection represented $27 \%$ of the total.

Table 3 shows SSI preventive actions in the preoperative period.
Table 3 shows that $88.5 \%$ of children used antibiotics in the preoperative period. The preoperative bath was performed in $61.5 \%$ of the sample, and chlorhexidine degermant was used in $92.3 \%$.

Through ETRCA it was possible to identify factors that may have contributed to the exposure to the risk of SSI, such as hypothermia, treatment with nasal mupirocin, endocarditis, glycemic disorders, hypotension, hypoxemia, cardiac catheterization with 24 hours after surgery, anasarca and pleural effusion. Also registered at ETRCA is the lack of hand sanitizing. It is important to emphasize that if it is not performed by one of the members of the surgical procedure, it becomes relevant because the brushing and degermation of hands is a unique condition for the prevention of infections in the surgical site. 
Table 2. Chatacteristics of the surgical procedure in children undergoing cardiac surgery. Fortaleza, Ceará, 2018.

\begin{tabular}{|c|c|c|}
\hline Type of surgery & $\mathrm{F}$ & $\%$ \\
\hline Corrective & 23 & 88,5 \\
\hline Reconstructive & 2 & 7,7 \\
\hline Substitutive & 1 & 3,8 \\
\hline Surgical time (hours) & $\mathrm{F}$ & $\%$ \\
\hline$<1$ hour & 2 & 7,7 \\
\hline t1 to 2 hours & 3 & 11,5 \\
\hline t2 to 4 hours & 10 & 38,5 \\
\hline -1 4 to 6 hours & 10 & 38,5 \\
\hline$>6$ hours & 1 & 3,8 \\
\hline Use of CPB & $\mathrm{F}$ & $\%$ \\
\hline Yes & 18 & 69,2 \\
\hline No & 8 & 30,8 \\
\hline CPB time (minutes) & $\mathrm{F}$ & $\%$ \\
\hline Up to 60 & 5 & 19,2 \\
\hline -160 to 90 & 6 & 23,0 \\
\hline f 90 to 120 & 7 & 27,0 \\
\hline Without CPB & 8 & 30,8 \\
\hline $\begin{array}{l}\text { Days after the procedure until } \\
\text { diagnosis of infection }\end{array}$ & $F$ & $\%$ \\
\hline Up to 2 & 4 & 15,4 \\
\hline-12 to 4 & 5 & 19,2 \\
\hline t 4 to 6 & 7 & 27,0 \\
\hline-16 to 8 & 6 & 23,0 \\
\hline$>8$ & 4 & 15,4 \\
\hline
\end{tabular}

Source: Elaborated by the author.

Table 3. Preventive actions for surgical site infection in preoperative period. Fortaleza, Ceará, 2018.

\begin{tabular}{|c|c|c|}
\hline Antibiotic therapy & $F$ & $\%$ \\
\hline Yes & 23 & 88,5 \\
\hline No & 3 & 11,5 \\
\hline Bath & $\mathrm{F}$ & $\%$ \\
\hline Yes & 16 & 61,5 \\
\hline No & 10 & 38,5 \\
\hline Skin preparation & $\mathrm{F}$ & $\%$ \\
\hline Yes & 24 & 92,3 \\
\hline No & 2 & 7,7 \\
\hline
\end{tabular}

Source: Elaborated by the author. 


\section{DISCUSSION}

In a research on the profile of children submitted to heart surgery, of the 55 children studied, 27 (49\%) were male, data that are similar to those of the present study ${ }^{7}$.

It is known that weight is an important factor in the rehabilitation of a disease ${ }^{8}$, stressing that low weight is a risk factor for contracting infections. The neonatal period ( 0 to 28 days) is considered critical, due to factors such as physiological changes in the newborn occurring in this phase and due to some severe congenital defects ${ }^{9}$.

The most common corrective surgeries are: closure of interventricular communication (IVC); closure of the interatrial canal (IAC); correction of tetralogy of Follot, tricuspid atresia, coarcectomy, pacemaker implantation, Blalock-Taussig, Glenn and pulmonary artery banding ${ }^{10}$.

The surgical time is a strong predictor of the total operating room time, depending on several factors related to the procedure, such as preoperative clinical conditions, type of surgical correction, intercurrences in the surgical act, among others ${ }^{11}$.

Cardiopulmonary bypass (CPB) is a necessary procedure in $90 \%$ of surgical cases. Age is a preexisting risk factor, the newborn being the most exposed to complications due to immaturity of the organism7. The CPB time directly influences the postoperative complications, because the longer the heart and lung remain motionless, the greater the damage caused, resulting in damage to pulmonary function and strength ${ }^{12}$.

Regarding the number of days after the procedure until the infection is diagnosed, it is stated that these infections are mostly diagnosed and reported in up to 4 to 6 days, but this period can vary with an overall average time of up to 18 days ${ }^{13}$.

It is known that, in surgical procedures, the team must rigorously follow the routine of SSI preventive actions, being the degermination of the hands and the use of an antiseptic product to remove the microorganisms, unique actions to reduce the microbial load ${ }^{14}$.

In this context, the nursing team must be attentive and continuously qualified, aiming at risk management, infection prevention and control. Within their duties, based on scientific evidence, nurses should develop a set of actions considered a priority, contributing to the noninstallation of adverse infectious events that cause harm to children and their families and that also interfere in the entire hospital context.

\section{CONCLUSION}

The present study identified variables related to SSI in children submitted to cardiac surgery, which are: age range, weight, type of surgery, surgical time, use of $\mathrm{CPB}$, CPB time, as well as actions to prevent SSI in the preoperative period.

In view of the findings, the need to implement preventive measures, surveillance of professionals involved in the care of children and implementation of institutional protocols, standard operating plans and bundles, as structured and organized ways to improve the processes and results of care of children undergoing heart surgery, is highlighted.

Currently, within the scope of actions related to infection prevention are the programs of government institutions, where guidelines of good practices that should be disseminated and applied by health professionals are presented, aiming at the continuous improvement of services provided.

Regarding the limitations of the study, data collection must be highlighted, since it is a retrospective study of document analysis, which requires an interpretation of the data already recorded, which implies the veracity of the documented information.

In this sense, it is worth emphasizing that the demand in the treatment process of SSI in children requires actions based on the knowledge of scientific evidence, but also involves social relations, characterizing transdisciplinary involvement. It is also necessary to emphasize that identifying related variables is relevant, since they can help to redefine the methods of care, the development of strategies that address the complexity of treatment and the ways of production and dissemination of knowledge about this undesirable event.

\section{FINANCING}

Study financed by the authors. 
AUTHOR'S CONTRIBUTION

\section{Conceptualization: Silva AL; Pontes TBC and Farias} MS; Methodology: Silva AL; Pontes TBC and Farias MS; Investigation: Silva AL; Pontes TBC; Farias MS and Riberito S; Writing - Original Draft: Silva AL; Pontes TBC; Farias
MS; Muniz Filha JM and Alexandre SG; Writing - Review and Editing: Silva AL; Pontes TBC; Farias MS; Muniz Filha JM and Alexandre SG; Funding Acquisition, Silva AL; Pontes TBC; Farias MS; Muniz Filha JM and Alexandre SG; Resources: Silva AL; Pontes TBC; Farias MS; Muniz Filha; Alexandre SG and Ribeiro S; Supervision: Silva AL.

\section{REFERENCES}

1. Centers for Disease Control and Prevention (CDC). Procedure-associated module: surgical site infection (SSI) event. Atlanta: CDC; 2016. [cited on 2 abr 2020]. Available at: http://www.cdc.gov/nhsn/pdfs/pscmanual/9pscssicurrent. pdf

2. Brasil. Ministério da Saúde. Critérios diagnósticos de infecções relacionadas à assistência à saúde. Brasília: Anvisa; 2017. [cited on 12 dez 2019]. Available at: http://portal. anvisa.gov.br/documents/33852/3507912/Caderno+2+-+Cr it\%C3\%A9rios+Diagn\%C3\%B3sticos+de+Infec\%C3\%A7\%C3 $\% A 30+$ Relacionada+\%C3\%A0+Assist\%C3\%AAncia+\%C3\%A0 +Sa\%C3\%BAde/7485b45a-074f-4b34-8868-61f1 e5724501

3. Brasil. Ministério da Saúde. Gabinete do Ministro. Portaria MS/GM n. 529, de 1 de abril de 2013. Institui o Programa Nacional de Segurança do Paciente (PNSP). Diário Oficial da União 2 abr 2013. [cited on 10 dez 2019]. Available at: http://bvsms.saude.gov.br/bvs/saudelegis/gm/2013/ prt0529_01_04_2013.html

4. Brasil. Ministério da Saúde, Agência Nacional de Vigilância Sanitária. Assistência segura: uma reflexão teórica aplicada à prática. Brasília: Anvisa; 2017. [cited on 10 dez 2019]. Available at: http://portal.anvisa.gov.br/ documents/33852/3507912/Caderno+1+-+Assist\%C3\%AAn cia+Segura++Uma+Reflex\%C3\%A3o+Te\%C3\%B3rica+Aplic ada+\%C3\%A0+Pr\%C3\%A1 tica/97881798-cea0-4974-9d9b077528 ea1573

5. Silva ACSS, Stipp MAC, Pereira FMV, Paes GO, Knupp VMAO. Clinical and laboratory variables associated with mortality outcome in the post-operative pediatric cardiac surgery. Esc Anna Nery. 2019;23(1):e20180147. https://doi. org/10.1590/2177-9465-ean-2018-0147

6. Martins T, Amante LN, Virtuoso JF, Sell BT, Wechi JS, Senna CVA. Fatores de risco para infecção do sítio cirúrgico em cirurgias potencialmente contaminadas. Texto Contexto - Enferm. 2018;27(3):e2790016. https://doi. org/10.1590/0104-070720180002790016

7. Oliveira JMA, Silva AMF, Cardoso SB, Lima FF, Zierer MS, Carvalho ML. Complicações no pós-operatório de cirurgia cardiovascular com circulação extracorpórea. Rev Interd. 2015;8(1):9-15.

8. Jardim PCBV. Excesso de peso, o risco cardiovascular do século. Arq Bras Cardiol. 2019;113(2):185-7. https://doi. org/10.5935/abc.20190171

9. Brasil. Ministério da Saúde, Secretaria de Atenção à Saúde, Departamento de Ações Programáticas Estratégicas. Atenção à saúde do recém-nascido: Guia para os profissionais de saúde. Brasília: Ministério da Saúde; 2014. [cited on 12 dez 2019]. Available at: https://portaldeboaspraticas.iff.fiocruz. br/biblioteca/atencao-a-saude-do-recem-nascido-guiapara-os-profissionais-de-saude-cuidados-gerais/

10. Graça Júnior CAG, Mendes JR, Dourado GOL, Rodrigues EM, Araújo RA, Queiroz AAFLN. Infecções em pacientes no pós-operatório em cirurgia cardíaca: uma revisão integrativa. Rev Pre Infec e Saúde. 2015;1(1):59-73. https:// doi.org/10.26694/repis.v1i1.3173

11. Costa Junior AS. Assessment of operative times of multiple surgical specialties in a public university hospital. Einstein. 2017;15(2):200-5. https://doi.org/10.1590/s167945082017gs3902

12. Marques MJS, Borges DL, Santos NP, Oliveira RL, Borges MGB, Costa $A C L$, et al. Perfil clínico epidemiológico de pacientes submetidos à utilização de marca-passo no pós-operatório de cirurgia cardíaca. Rev Pesq Saúde. 2017;18(3):168-72.

13. Braz NJ, Evangelista SS, Evangelista SS, Garbaccio JL, Oliveira AC. Infecção do sítio cirúrgico em pacientes submetidos a cirurgias cardíacas: uma análise do perfil epidemiológico. Revista RECOM. 2018;8:e1793. https://doi.org/10.19175/ recom.v8i0.1793

14. Brasil. Agência Nacional de Vigilância Sanitária (Anvisa). Medidas de prevenção de infecção relacionada à assistência à saúde. Brasília: Anvisa; 2017. [cited on 10 dez 2019]. Available at: http://portal.anvisa.gov.br/ documents/33852/3507912/Caderno+4+-+Medidas+de+Pr even\%C3\%A7\%C3\%A3o+de+Infec\%C3\%A7\%C3\%A3o+Relac ionada+\%C3\%A0+Assist\%C3\%AAncia+\%C3\%A0+Sa\%C3\%B Ade/a3f23dfb-2c54-4e64-881c-fccf9220c373 